\title{
Biological Parameters and Molecular Markers of Clone CL Brener - The Reference Organism of the Trypanosoma cruzi Genome Project
}

\author{
Bianca Zingales ${ }^{+}$, Maria Elizabeth S Pereira*, Kátia A Almeida**, \\ Eufrosina S Umezawa**, Nédia S Nehme***, Riva P Oliveira****, \\ Andrea Macedo****, Ricardo P Souto
}

Instituto de Química, Universidade de São Paulo, Caixa Postal 26.077, 05599-970 São Paulo, SP, Brasil *Centro de Pesquisas René Rachou - Fiocruz, Belo Horizonte, MG, Brasil **Instituto de Medicina Tropical, Universidade de São Paulo, São Paulo, SP, Brasil ***Instituto Oswaldo Cruz, Rio de Janeiro, RJ, Brasil ****Instituto de Ciências Biológicas, Universidade Federal de Minas Gerais, Belo Horizonte, MG, Brasil

Clone CL Brener is the reference organism used in the Trypanosoma cruzi Genome Project. Some biological parameters of CL Brener were determined: (a) the doubling time of epimastigote forms cultured in liver infusion-tryptose (LIT) medium at $28^{\circ} \mathrm{C}$ is $58 \pm 13 \mathrm{hr}$; (b) differentiation of epimastigotes to metacyclic trypomastigotes is obtained by incubation in LIT-20\% Grace's medium; (c) trypomastigotes infect mammalian cultured cells and perform the complete intracellular cycle at 33 and $37^{\circ} \mathrm{C} ;(d)$ blood forms are highly infective to mice; (e) blood forms are susceptible to nifurtimox and benznidazole. The molecular typing of CL Brener has been determined: (a) isoenzymatic profiles are characteristic of zymodeme ZB; (b) PCR amplification of a $24 S \alpha$ ribosomal RNA sequence indicates it belongs to T. cruzi lineage 1; (c) schizodeme, randomly amplified polymorphic DNA (RAPD) and DNA fingerprinting analyses were performed.

Key words: CL Brener - Trypanosoma cruzi - Genome Project - biological characteristics - molecular typing

At difference with other Parasite Genome Projects, the participants of the Trypanosoma cruzi network present in the Trypanosomatid Genome Planning Meeting held in Rio de Janeiro in April 1994 decided to select one reference clone (CL Brener) to be used by all members. This clone derives from the CL strain which presents all important characteristics of T. cruzi: (a) it was isolated from Triatoma infestans, a strictly domiciliary vector (Brener \& Chiari 1963); (b) it differentiates in liquid medium; (c) it infects cell monolayers (Alcantara \& Brener 1978); (d) it has preferential parasitism of heart and muscle cells (Melo \& Brener 1978); (e) it presents defined parasitemia curves and mortality in mice (Brener 1977); (f) it shows a clear acute phase in accidentally infected humans (Z Brener, personal communication); and (g) it is highly susceptible to drugs used clinically in Chagas disease (Filardi \& Brener 1987).

Financial support: UNDP/World Bank/WHO Special Programme for Research and Training in Tropical Diseases and FAPESP, Fundação de Amparo à Pesquisa do Estado de São Paulo.

${ }^{+}$Corresponding author. Fax: +55-11-815.5579. E-mail: bszodnas@quim.iq.usp.br

Received 20 August 1997

Accepted 10 September 1997
Clone CL Brener was recently isolated by Professor Zigman Brener and MES Pereira (Centro de Pesquisas René Rachou-Fiocruz, Belo Horizonte) from the blood of mice infected with the CL parental strain.

The initial task attributed to our group was the definition of the biological characteristics of CL Brener clone as well as of molecular markers to be used to genetically characterize this organism. Furthermore, our laboratory (Instituto de Química, Universidade de São Paulo) was chosen as a Reference Laboratory for storage and distribution of the clone to members of the T. cruzi Genome Project.

\section{BIOLOGICAL AND PARASITOLOGICAL PARA-} METERS OF CLONE CL BRENER

Cultivation conditions and differentiation into metacyclic forms - Epimastigote forms were cultured in LIT medium containing $10 \%$ calf serum (Castellani et al. 1967), at $28^{\circ} \mathrm{C}$ without agitation. A doubling time of $58 \pm 13 \mathrm{hr}$ was determined. Spontaneous differentiation of epimastigote into metacyclic forms varied from 25 to $40 \%$. After 19 weeks of subculturing, the differentiation capacity was drastically reduced to $5-10 \%$.

Differentiation into metacyclic forms could be induced in LIT medium with different proportions 
of Grace's medium (20-55\% v/v). After seven to ten days, $50-80 \%$ differentiation into metacyclic forms was obtained. Metacyclics could be separated from epimastigotes by chromatography in DEAE-cellulose (Whatman DE-52) columns. Differentiation in LIT:Grace medium was also reduced after prolonged subcultivation of the CL Brener clone in LIT medium.

Infectivity to cultured mammalian cells - Previous studies on the morphogenesis of intracellular trypomastigotes in cell culture indicated that the amastigote-to-trypomastigote differentiation of the CL strain took place at $33^{\circ} \mathrm{C}$ but was inhibited at $37^{\circ} \mathrm{C}$ (Brener et al. 1976). This phenomenon was not observed with other strains (e.g. Y, Gilmar, G, etc.) where differentiation to intracellular trypomastigotes occurred both at $33^{\circ} \mathrm{C}$ and $37^{\circ} \mathrm{C}$. The thermosensitivity presented by the CL strain led to the hypothesis that this strain may represent a natural "regulatory mutant" where specific gene(s) involved in differentiation have suffered mutation(s) (cf. Brener et al. 1976).

We investigated whether CL Brener also presented this temperature-dependent characteristic. Monolayers of LLC-MK ${ }_{2}$ cells were exposed to a suspension of tissue culture trypomastigotes (TCT) of CL Brener employing a parasite/cell ratio of 100:1. For comparison, experiments were conducted in parallel with TCT of the Y strain of $T$. cruzi (Silva \& Nussenzweig 1953). After $3 \mathrm{hr}$ exposure at 33 or $37^{\circ} \mathrm{C}$, the percentage of infected cells and the interiorization index (parasites/cell) were determined as described (Zingales et al. 1982). Data of four independent experiments are shown in Table I. The number of TCT liberated in the culture medium of cell monolayers after five to eight days of infection (parasite/cell ratio 8:1) in cultures maintained at 33 or $37^{\circ} \mathrm{C}$ was also determined (Table II). Data indicate that clone CL Brener is able to penetrate and differentiate in cultured-mammalian cells at both temperatures. In addition, the experiments suggest that the $\mathrm{Y}$ strain performs more efficiently the intracellular cycle when compared to CL Brener.
TABLE II

Liberation of trypomastigotes in the supernatant of LLC-MK 2 cell monolayers. Data in $10^{6}$ parasites $/ \mathrm{ml}$

\begin{tabular}{cllcr}
\hline \multirow{2}{*}{$\begin{array}{l}\text { Days after } \\
\text { infection }\end{array}$} & \multicolumn{2}{c}{ CL Brener clone } & \multicolumn{2}{c}{ Y strain } \\
\cline { 2 - 5 } & $33^{\circ} \mathrm{C}$ & $37^{\circ} \mathrm{C}$ & $33^{\circ} \mathrm{C}$ & $37^{\circ} \mathrm{C}$ \\
\hline 5 & 0.2 & 0.1 & 1.5 & 1.25 \\
6 & 1 & 2 & 10 & 10.75 \\
7 & 1.5 & 2.75 & 7.5 & 13.5 \\
8 & 3.5 & 0.7 & 3.8 & 2 \\
\hline
\end{tabular}

Infectivity to mice - Parasitemia curves and mortality were determined in Balb/c mice inoculated i.p. with $5 \times 10^{5}$ LIT:Grace-derived metacyclic trypomastigotes of CL Brener clone and of the CL strain. Pre-patent periods of 6-7 days were observed. Data indicate that metacyclic forms of the CL-parental strain are more virulent than those of CL Brener clone.

Balb/c mice were inoculated i.p. $5 \times 10^{3}$ blood trypomastigotes. Pre-patent periods of 6-7 days were also observed for both clone CL Brener and the CL strain. Parasitemia curves were ascending reaching $2 \times 10^{6}$ trypomastigotes/ml 15 days after inoculation. Mortality was $100 \%$ on day 16 . Similar results were observed for the CL strain.

Susceptibility to chemotherapeutic agents Parasite sensitivity to benznidazole and nifurtimox was assayed according to the protocol described by Filardi and Brener (1984). Two groups of $\mathrm{Balb} / \mathrm{c}$ mice were inoculated with $10^{4}$ blood trypomastigotes of the CL Brener clone and the CL parental strain, respectively. In the chronic phase the animals received $500 \mathrm{mg} / \mathrm{kg}$ of either drug by oral route. Parasite clearance was measured in $5 \mathrm{~mm}^{3}$ blood withdrawn from the animal tail, 3 and $6 \mathrm{hr}$ after drug administration. A 95\% clearance was observed $6 \mathrm{hr}$ after either benznidazole or nifurtimox. It was concluded that the CL Brener clone is extremely sensitive to both nitroheteroxyclic drugs and that this sensitivity is equal to that observed for the parental CL strain, corroborating

TABLE I

Interiorization of tissue culture trypomastigotes into $\mathrm{LLC}_{-} \mathrm{MK}_{2}$ cells after $3 \mathrm{hr}$ exposure

\begin{tabular}{cccccccc}
\hline \multicolumn{3}{c}{ CL Brener clone } & \multicolumn{3}{c}{ Y strain } \\
\hline \multicolumn{3}{c}{$33^{\circ} \mathrm{C}$} & \multicolumn{2}{c}{$37^{\circ} \mathrm{C}$} & \multicolumn{2}{c}{$33^{\circ} \mathrm{C}$} & \multicolumn{2}{c}{$37^{\circ} \mathrm{C}$} \\
\hline $\begin{array}{c}\text { Infected } \\
\text { cells }(\%)\end{array}$ & $\begin{array}{c}\text { Parasites } \\
\text { /cell }\end{array}$ & $\begin{array}{c}\text { Infected } \\
\text { cells (\%) }\end{array}$ & $\begin{array}{c}\text { Parasites } \\
\text { /cell }\end{array}$ & $\begin{array}{c}\text { Infected } \\
\text { cells }(\%)\end{array}$ & $\begin{array}{c}\text { Parasites } \\
\text { /cell }\end{array}$ & $\begin{array}{c}\text { Infected } \\
\text { cells }(\%)\end{array}$ & $\begin{array}{c}\text { Parasites } \\
\text { /cell }\end{array}$ \\
\hline $19 \pm 4$ & 1.1 & $39 \pm 5$ & 1.4 & $44 \pm 13$ & 1.9 & $53 \pm 8$ & 1.7 \\
$13 \pm 1$ & 1.1 & $57 \pm 6$ & 1.7 & $32 \pm 2$ & 1.3 & $54 \pm 2$ & 1.8 \\
$26 \pm 4$ & 1.2 & $56 \pm 3$ & 1.9 & $53 \pm 9$ & 1.7 & $50 \pm 7$ & 1.4 \\
$27 \pm 3$ & 1.1 & $63 \pm 4$ & 1.9 & - & - & $47 \pm 6$ & 1.7 \\
\hline
\end{tabular}


previous reports on this strain (Filardi \& Brener 1987). These observations should be taken into consideration in possible accidental laboratory contamination with CL Brener.

\section{MOLECULAR TYPING}

Isoenzymatic profiles and definition of zymodeme group - Following the protocol described by Romanha et al. (1979) isoenzymatic profiles were determined for six enzymes: alanine aminotransferase (ALAT), glucose phosphate isomerase (GPI), glucose-6-phosphate isomerase (G6PD), aspartate aminotransferase (ASAT), phosphoglucomutase (PGM) and malic enzyme (ME) and compared to standard T. cruzi zymodemes. CL Brener clone and the CL parental strain presented identical isoenzymatic profiles (Fig. 1) characteristic of zymodeme ZB (Romanha et al. 1979).

Analysis of a dimorphic sequence of the $24 S \alpha$ ribosomal RNA gene - We have previously shown that the D7a divergent domain of the $24 \mathrm{~S} \alpha$ ribosomal RNA gene of T. cruzi presents sequence dimorphism among parasite strains (Souto \& Zingales 1993). PCR amplification of a specific region of this gene, employing oligonucleotides D71 and D72, originates fragments of $125 \mathrm{bp}$ (Group 1 isolates) or 110bp (Group 2 isolates) (Souto \& Zingales 1993). Analogous experiments were done with the CL parental strain and CL Brener clone, originating 125bp fragments. Both products were cloned into the HincII site of M13mp19 and sequenced. Sequence alignment indicate $98 \%$ similarity of both CL Brener and CL parental strain to the $24 \mathrm{~S} \alpha$ rDNA consensus sequence of Group 1-isolates (Fig. 2). The nucleotide sequence of the 125bp DNA fragment of CL Brener has been deposited in GenBank under the accession number U73959.

\section{ISOENZYMATIC PROFILES}

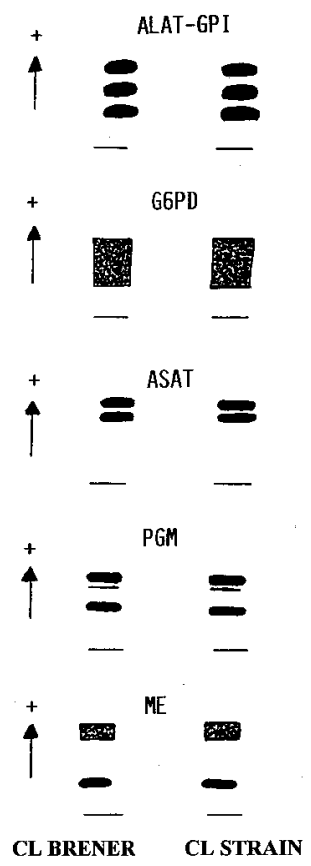

Fig. 1: diagrammatic representation of the isoenzymatic profiles of six enzymes from clone CL Brener and the parental CL strain. For enzyme abbreviations see text.

Schizodeme analysis - The technique of schizodeme analysis for genotypic characterization of trypanosomatids was introduced by Morel et al. (1980). Schizodeme analysis of CL Brener clone was done according to Gonçalves et al. (1984). The patterns obtained with five restriction enzymes indicate that the schizodeme of CL Brener clone is the same as that of the CL parental strain. Data were published elsewhere (Zingales et al. 1997).

\section{$Y$ (Lineage 1) CL and CL Brener Din28 (Lineage 2)}

Y (Lineage 1) $C L$ and $C L$ Brener Dm28 (Lineage 2)
10 AAGGTGCGTCGACAGTGTGGGAGTCTTTTTTTTTTTTCTACCTCTCTTTC AAGGTGCGTCGACAGTGTGGGAGTCTTTTTTTTTTT--TACCTCTCTTTC AAGGTGCGTCGACAGTGTGGGGGAGTCTCTTCTTCTTTCCCCCCTCTCTC

$\begin{array}{cc}60 & 70 \\ \text { CTTCTCTTCACGGGGGGGTTATATA } & \text { CTTCTCTTCACGGGGGGGTTATATA } \\ \text { CTTTTGGTGTGGGGTGTGGGAGGAAGA } & \\ 110 & 120 \\ \text { CCTTACTGTTCGGCCATTCTGAAAA } \\ \text { CCTTACTGTTCGGCCATTCTGAAAA } \\ \text { TGAAAA }\end{array}$

Fig. 2: sequence of the target region of the D7a divergent domain of the 24S $\alpha$ ribosomal RNA gene of clone CL Brener compared to analogous sequences of the CL, Y (group 1) and Dm28 (group 2) strains. 
Randomly amplified polymorphic DNA analysis - The basic protocol by Steindel et al. (1993) for arbitrarily primed polymerase chain reaction (AP-PCR) was followed. DNA was submitted to PCR with seven different primers including M13F, M13R, $\lambda \mathrm{gt} 11 \mathrm{~F}$, and $\lambda \mathrm{gt} 11 \mathrm{R}$. A complex multiband profile was observed for each primer. On average $18 \pm 7$ bands were detected, varying in intensity and size according to the primer used (Zingales et al. 1997).

DNA fingerprinting - It has been shown that the human multilocus probe 33.15 (Jeffreys et al. 1985 ) is capable of identifying minisatellites in $T$. cruzi genome, generating a strain-specific complex banding pattern typical of DNA fingerprinting (Macedo et al. 1992). Genomic DNA of CL Brener was digested with BspRI or HinfI and electrophoresed in $0.8 \%$ agarose gels. Southern blots were hybridized to the 33.15 biotinylated probe. A complex multiband profile with approximately 20 bands varying in intensity and size from $2 \mathrm{~kb}$ to 23 $\mathrm{Kb}$ was obtained. Bands of lower molecular weight were also detected (Fig. 3).

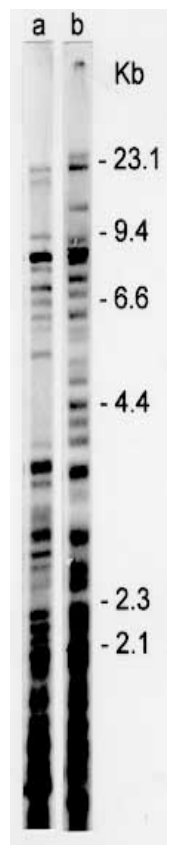

Fig.3: DNA fingerprinting of CL Brener. Total DNA was digested with BspRI (a) or Hinf I (b). The Southern blot was hybridized to the 33.15 multilocal probe. Molecular weight markers are indicated.

\section{REFERENCES}

Alcantara A, Brener Z 1978. The in-vitro interaction of Trypanosoma cruzi blood stream forms and mouse peritoneal macrophages. Acta Trop 35: 209-219.

Brener Z 1977. Intraspecific variations in Trypanosoma cruzi: two types of parasite populations presenting distinct characteristics. PAHO Sci Pub Washington 347: 11-21.
Brener Z, Chiari E 1963. Variações morfológicas observadas em diferentes amostras de Trypanosoma cruzi. Rev Inst Med Trop São Paulo 5: 220-224.

Brener Z, Golgher R, Bertelli MS, Teixeira JA 1976. Strain-dependent thermosensitivity influencing intracellular differentiation of Trypanosoma cruzi in cell culture. J Protozool 23: 147-150.

Castellani O, Ribeiro LV, Fernandes JF 1967. Differentiation of Trypanosoma cruzi in culture. J Protozool 14: 447-451.

Filardi LS, Brener Z 1984. A rapid method for testing in vivo the susceptibility of different strains of Trypanosoma cruzi to active chemotherapeutic agents. Mem Inst Oswaldo Cruz 79: 221-225.

Filardi LS, Brener Z 1987. Susceptibility and natural resistance of Trypanosoma cruzi strains to drugs used clinically in Chagas disease. Trans $R$ Soc Trop Med Hyg 81: 755-759.

Gonçalves AM, Nehme N, Morel CM 1984. Trypanosomatids characterization by schizodeme analysis, p.95-109. In CM Morel Genes and Antigens of Parasites - A Laboratory Manual, Fundação Oswaldo Cruz, Rio de Janeiro.

Jeffreys AJ, Wilson V, Thein SL 1985. Hypervariable 'minisatellite' regions in human DNA. Nature 314: 67-73.

Macedo AM, Martins MS, Chiari E, Pena SDJ 1992. DNA fingerprinting of Trypanosoma cruzi: a new tool for characterization of strains and clones. $\mathrm{Mol}$ Biochem Parasitol 55: 147-154.

Melo RC, Brener Z 1978. Tissue tropism of different Trypanosoma cruzi strains. J Parasitol 64: 475-482.

Morel C, Chiari E, Plessmann Camargo E, Mattei DM, Romanha AJ, Simpson L 1980. Strains and clones of Trypanosoma cruzi can be characterized by restriction endonucleases fingerprint of kinetoplast DNA molecules. Proc Natl Acad Sci USA 77: 68106814.

Romanha AJ, Pereira AAS, Chiari E, Kilgour V 1979. Isoenzyme patterns of cultured Trypanosoma cruzi: changes after prolonged subculture. Comp Biochem Physiol 62B: 139-142.

Silva LHP, Nussenzweig V 1953. Sobre uma cepa de Trypanosoma cruzi altamente virulenta para o camundongo branco. Folia Clin Biol 20: 191-207.

Souto RP, Zingales B 1993. Sensitive detection and strain characterization of Trypanosoma cruzi by amplification of a ribosomal RNA sequence. Mol Biochem Parasitol 62: 45-52.

Steindel M, Dias Neto E, Menezes CLP, Romanha AJ, Simpson AJG 1993. Random amplified polymorphic DNA analysis of Trypanosoma cruzi strains. Mol Biochem Parasitol 60: 71-80.

Zingales B, Andrews NW, Kuwajima VY, Colli W 1982. Cell surface antigens of Trypanosoma cruzi: possible correlation with the interiorization process in mammalian cells. Mol Biochem Parasitol 6: 111-124.

Zingales B, Pereira MES, Oliveira RP, Almeida KA, Umezawa EU, Souto RP, Vargas N, Cano MI, Silveira JF, Nehme NS, Morel CM, Brener Z, Macedo A 1997. Trypanosoma cruzi genome project: biological characteristics and molecular typing of clone CL Brener. Acta Trop (in press). 